Traces of War in Virginia Woolf's Night and Day

Michael H. Whitworth

Professor of Modern Literature and Culture, English Faculty, University of Oxford Tutorial Fellow, Merton College, Oxford

michael.whitworth@ell.ox.ac.uk 


\title{
Traces of War in Virginia Woolf's Night and Day*
}

Michael H. Whitworth

\begin{abstract}
Katherine Mansfield's review of Virginia Woolf's Night and Day (1919) has dominated criticism of the novel and contributed to its critical neglect, but Mansfield's belief that the novel ignores the First World War has never been challenged. The present essay identifies the novel's oblique references to the war and to combat. It considers the novel's status as a historical novel: its awareness that the pre-war era is irretrievably lost, and its creation of situational ironies for its characters. It considers the themes of isolation, insulation, and near-obliviousness, and the awareness of sounds at the edge of consciousness, as symptomatic of the novel's war-time moment.
\end{abstract}

Keywords: First World War; historical novel; Virginia Woolf; Katherine Mansfield; soundscapes

Virginia Woolf's second novel, Night and Day (1919) has a reputation as the 'most neglected' of her works, a novel 'now little read', and 'a kind of dinosaur'. ${ }^{1}$ The reasons are

\footnotetext{
* Papers related to this essay were given at the 2018 Annual Conference on Virginia Woolf, held at the University of Kent, Canterbury, and at the September 2019 meeting of the
} Virginia Woolf Society Great Britain, at Wolfson College, Oxford; I am grateful to participants at both meetings for their comments and suggestions.

1 Julia Briggs, Reading Virginia Woolf (Edinburgh: Edinburgh University Press, 2006), p. 43; Vincent Sherry, The Great War and the Language of Modernism (Oxford: Oxford University Press, 2003), p. 266; H. Porter Abbott, 'Old Virginia and the Night Writer: Origins of Woolf's Narrative Meander', in Inscribing the Daily: Critical Essays on Women's Diaries, ed. by Suzanne L. Bunkers and Cynthia A. Huff (Amherst: University of Massachusetts Press, 1996), pp.236-51 (p.236). 
not far to seek: in its apparent formal conservatism, it is worlds apart from her later work, and even from contemporaneous experimental fictions such as 'The Mark on the Wall' and 'Kew Gardens'. Katherine Mansfield's estimate of it, articulated in her November 1919 review for The Athenaeum, looms large in its critical history, particularly her association of the novel's formal conservatism with its apparent denial of the First World War. Mansfield's review figured the novel as a ship returning to port, a 'strange sight' because of 'her aloofness, her air of quiet perfection, her lack of any sign that she has made a perilous voyage--the absence of any scars'. Mansfield concluded the review by remarking 'We had thought that this world was vanished forever, that it was impossible to find on the great ocean of literature a ship that was unaware of what has been happening'. ' What had been happening' is ambiguous, and may refer to the experiments of modern writers, or to the war, or to both. In a contemporaneous letter to her husband, the Athenaeum's editor John Middleton Murry, Mansfield was more explicit about her objections:

The war never has been, that is what its message is. I dont want G. forbid mobilisation and the violation of Belgium - but the novel cant just leave the war out. There must have been a change of heart. ${ }^{3}$

\footnotetext{
${ }^{2}$ K.M. [Katherine Mansfield], 'A Ship Comes into the Harbour', Athenaeum, 21 November 1919, p. 1227.

${ }^{3}$ Mansfield, letter to John Middleton Murry, The Collected Letters of Katherine Mansfield, ed. by Vincent O'Sullivan and Margaret Scott, 5 vols (Oxford: Clarendon, 1984-2008), III, 82.
} 
Mansfield, whose brother Leslie had been killed accidentally during grenade training in October 1915, seems to wished for a combination of directness and allusiveness unachievable by any writer. The present essay will argue that Night and Day does not altogether leave out the war. It was conceived and written during the war: it began in early 1915 as 'poor Effie's story' or 'The Third Generation'; composition was curtailed by Woolf's breakdown later in 1915, but resumed by mid-1916; Woolf completed a first draft shortly after the armistice in November $1918 .{ }^{4}$

Mansfield's image of the novel as a vessel isolated from the concerns of 1914-1918 takes its position from the opening scene of the novel. As Ralph Denham enters the comfortable Chelsea home of the Hilbery family, he is aware of its isolation. He feels

as if a thousand softly padded doors had closed between him and the street outside. ... With the omnibuses and cabs still running in his head, and his body still tingling with his quick walk along the streets and in and out of traffic and foot-passengers, this drawing-room seemed very remote and still. ${ }^{5}$

On the one hand, a world of traffic, noise, and over-stimulated nerves -- in short, a recognisable kind of urban modernity -- and on the other, a slow-paced and restrictive

\footnotetext{
${ }^{4}$ Woolf, The Diary of Virginia Woolf, ed. by Anne Olivier Bell, 5 vols (London: Hogarth 19771984), I, 4, 19; The Letters of Virginia Woolf, ed. Nigel Nicolson and Joanne Trautmann Banks, 6 vols (London: Hogarth, 1975-1980), II, 107; Diary, I, 221.

${ }^{5}$ Virginia Woolf, Night and Day (London: Duckworth, 1919), p. 327. All subsequent in-text references are to this edition.
} 
world of tradition and convention. There is more to be said about the theme of isolation, but, in short, in the present article I would like to suggest that Woolf was fully aware of the theme, and that the distance between the street and the drawing-room is articulated in terms that recall the distance between Flanders and the home front.

The war is present in three different though overlapping ways. Firstly, Night and Day makes oblique references to the war and to combat in general. Secondly, it registers the First World War by dint of being a historical novel about a pre-war era that, though close in time, was already irretrievably lost; the novel creates occasions for the reader to reflect on the ironies of historical change. Finally, it returns repeatedly to the theme of isolation just noted, and a related theme of haunting; it is concerned with how people can be almost oblivious of events occurring in near proximity, and how can they can be aware of them in tangential and apparitional forms. Mansfield was not an inattentive reader of the novel, but present-day readers, knowing the extent to which allusiveness and obliquity became, in Woolf's later novels, part of her method for engaging with political themes, are equipped with other approaches to reading her work. Although Night and Day is ostensibly in the realist tradition, these approaches may be fruitfully applied to it.

The large critical literature dealing with Woolf's response to war and militarism has almost nothing to say about Night and Day: it is mentioned only in passing in the influential collection of essays Virginia Woolf and War (1991) and in Karen Levenback's 1999 monograph; it does not appear in the essay-collection The Theme of Peace and War in Virginia Woolf's War Writings (2010). ${ }^{6}$ The book chapter that most directly addresses the

\footnotetext{
${ }^{6}$ Virginia Woolf and War: Fiction, Reality, and Myth, ed. by Mark Hussey (Syracuse, N.Y.: Syracuse University Press, 1991); Karen L. Levenback, Virginia Woolf and the Great War
} 
subject, by Helen Wussow, makes the connection at a highly abstracted level: the 'antipathies' present in dialogue in the novel 'have their social correlative in the First World War'; Ralph and Katharine, for example, engage in 'a belligerent hurling of accusatory stereotypes'. ${ }^{7}$ Wussow does not seek to situate the novel historically. The critical literature on Night and Day has been most illuminating when approaching it from the angle of suffrage fiction or its depiction of the city, but in doing so has left Mansfield's claim unchallenged. ${ }^{8}$

Critics have generally positioned Night and Day in a narrative of Woolf's aesthetic development in which it is the 'classical' or 'traditional' exercise that precedes the modernist breakthrough of Jacob's Room (1922). As Amber Regis has written, the novel is a 'hostage to fortune': 'To read it now is always to look for what comes next.' 9 One way of breaking this pattern would be deliberately to refuse reference to Woolf's later works, or indeed to the contemporaneous experimental fictions, and to attempt to see Night and Day

(Syracuse, N.Y.: Syracuse University Press, 1999); The Theme of Peace and War in Virginia Woolf's War Writings, ed. by Jane Wood (Lewiston: Edwin Mellen, 2010).

${ }^{7}$ Helen Wussow, The Nightmare of History: The Fictions of Virginia Woolf and D.H. Lawrence (Bethlehem: Lehigh University Press, 1998), p. 103.

${ }^{8}$ Sowon S. Park, 'Suffrage and Virginia Woolf: "The Mass behind the Single Voice"', Review of English Studies, 56 (2005), pp. 119-134; Clara Jones, Virginia Woolf: Ambivalent Activist (Edinburgh: Edinburgh University Press, 2016), pp. 77-92; Susan M. Squier, Virginia Woolf and London: The Sexual Politics of the City (Chapel Hill : University of North Carolina Press, 1985), pp.71-88; H. Porter Abbott, 'Old Virginia and the Night Writer' (see note 1).

${ }^{9}$ Amber K. Regis, 'Only half a vision', TLS, 6 September 2019, p.15. 
in the terms of its own cultural moment. However, we can learn from the reading strategies that have been applied to the later novels and return to Night and Day with a clearer sight. Critics working on, for example, 'The Mark on the Wall', Jacob's Room, and The Years, have recognised that Woolf's oblique methods for dealing with material that was personally or politically charged necessitate a mode of reading attuned to the contemporary resonances of language and topographical reference: Mitchell Leaska's account of the cryptic realism of The Years was pioneering, though Leaska's reading of that novel pointed towards private, biographical material; David Bradshaw's and Vara Neverow's accounts of Jacob's Room draw on publicly available resonances, as does Paul Saint-Amour's account of 'The Mark on the Wall. ${ }^{10}$ Rather than looking for what comes next in Woolf's oeuvre, and measuring Night and Day as deficient by comparison, we can look at what came next, and, returning to Night and Day, read it more obliquely.

\section{'Weapon[s] of underhand stealth'}

The oblique references to the war and to wars are matters of vocabulary and imagery. At times Woolf employs a distinctly martial vocabulary. For example, in Chapter 24, when

\footnotetext{
${ }^{10}$ Mitchell Leaska, 'Virginia Woolf, The Pargeter: A Reading of The Years', Bulletin of the New York Public Library, 80 (1977), pp. 172-210; David Bradshaw, Winking, buzzing, carpetbeating: reading Jacob's Room (Southport: Virginia Woolf Society of Great Britain, 2003); Vara Neverow, 'Woolf's Editorial Self-Censorship and Risk-Taking in Jacob's Room', in Virginia Woolf and the Literary Marketplace, ed. by Jeanne Dubino (Basingstoke: Macmillan, 2010), pp. 57-71; Paul Saint-Amour, Tense Future: Modernism, Total War, Encyclopedic Form (New York: OUP, 2015), pp. 103-11.
} 
Ralph telephones Katharine to make arrangements for their meeting at Kew, Katharine mildly resents being forced to decide, and the narrator describes her as feeling 'impinged upon the point of a bayonet'. ${ }^{11}$ In her edition of the novel, Briggs speculated that 'impinged' was a mistake for 'impaled', ${ }^{12}$ but one might rather think of it as a euphemism, as if Woolf both recognised and resisted the implications of the metaphor and its reference to battle. The scene that introduces Ralph's position within the Denham family also makes use of the language of conflict:

He reflected, with a growing sense of injury, that almost every one of his actions since opening the door of his room had been won from the grasp of the family system. [...] the room itself, the gas-fire, the arm-chair-all had been fought for; the wretched bird, with half its feathers out and one leg lamed by a cat, had been rescued under protest; but what his family most resented, he reflected, was his wish for privacy. To dine alone, or to sit alone after dinner, was flat rebellion, to be fought with every weapon of underhand stealth or of open appeal. Which did he dislike most-deception or tears? But, at any rate, they could not rob him of his thoughts; they could not make him say where he had been or whom he had seen. (20)

The passage is not allegorical or systematic: Ralph is both the warrior and the humanitarian; if the language of victory and weapons suggests military action, his resentment of the

\footnotetext{
${ }^{11}$ Virginia Woolf, Night and Day (London: Duckworth, 1919), p. 327. All subsequent in-text references are to this edition.

12 Julia Briggs, ed., Night and Day (London: Penguin, 1992), p. 447.
} 
family's interference with his individual liberties suggests pacifism. Ralph's rook is of particular interest: Ralph's kindness to it is consistent with his later feeding of sparrows, but its specific injury, its lame leg, hints at the injuries of returning soldiers. Although Woolf's most striking account of war-wounded soldiers as 'dreadful looking spiders' on crutches at Waterloo Station post-dates Night and Day by several years, she would have seen injured men in Richmond and in central London; she certainly had the opportunity to read Siegfried Sassoon's poem 'The One-Legged Man', in which a soldier's amputation is a blessing, when she reviewed The Old Huntsman and Other Poems in May $1917 .{ }^{13}$

In the following chapter, we are introduced to Mrs Hilbery's fragmentary compositions, which, when she and Katharine re-read them, resemble 'triumphal arches standing upon one leg' (36). The phrase occurs mid-sentence, which does not encourage us to pause and reflect, but it is packed with extraordinary implications. It is an almost oxymoronic image: arches cannot stand on one leg, except through some feat of architectural engineering that was unknown in Woolf's time. If an arch was not designed and built in this way, it must have been damaged through some natural or -- more importantly -- man-made disaster: the image suggests photographs of damaged buildings on the continent; it suggests that the triumph of war is short-lived, as the monuments of triumph will themselves in time enter the cycle of destruction. Moreover, the image again

\footnotetext{
${ }^{13}$ Woolf, Diary, II, 93; Siegfried Sassoon, 'The One-Legged Man', in The Old Huntsman and other poems (London: Heinemann, 1917), p. 43; Woolf, 'Mr Sassoon's Poems', in Essays of Virginia Woolf, ed. by Andrew McNeillie and Stuart N. Clarke, 6 vols (London: Hogarth,
} 1984-2011), II, 119-22. 
suggests the victims of war: arches cannot stand on one leg, but humans can, albeit unsteadily and usually with the aid of crutches.

The martial metaphors that were introduced in relation to Ralph and his family return, rather more pointedly, in relation to the suffrage society at which Mary Datchet works. Chapter 14, the scene of the society's committee meeting, opens with the phrase 'Mr Clacton was in his glory' (171). The sentence glances at Christian uses of the phrase 'in his glory', which stem from the Gospel of St Matthew:

When the Son of man shall come in his glory, and all the holy angels with him, then shall he sit upon the throne of his glory: / And before him shall be gathered all nations: and he shall separate them one from another, as a shepherd divideth his sheep from the goats: (Matthew 25.31-32).

By implication, Mr Clacton considers himself to be the millenarian Messiah, his chair at the head of the table is a throne, and the gathered committee members are the nations of the world. A few paragraphs further on, Mary realises that as Secretary to the Committee, she should have been 'shepherding' her colleagues, which further suggests the biblical resonances (173). But, as Clara Jones has noted, 'glory' and Mr Clacton's delight in other people's 'obedience' to his orders, also suggests the traditional language of military glory, 'dismantled', as Jones puts it, by the context of a small committee meeting. ${ }^{14}$ Mary, distracted and disengaged from the meeting, also finds herself committed to the opinion that 'now was the time to strike hard' against the 'old foes of the public good' (173). When

${ }^{14}$ Jones, Virginia Woolf: Ambivalent Activist, pp. 84-85. 
Mary has confessed to Miss Markham that her friends think 'all this kind of thing' to be useless, and Miss Markham has dismissed them 'with a little laugh', we are told of the committee that 'their legions charged the foe' (174). When Mary returns to work after her Christmas break in Lincolnshire, Mr Clacton is still talking in terms of the 'enemy' and 'the offensive', and has 'marshalled' facts in leaflets (269-70); he has created what sounds like an operations-room map, 'dotted with little pins' (269). He is primarily a bureaucrat, but one characterized in a military language.

Mrs Seal is similarly attached to martial metaphors. As she and Mary discuss the long duration of the campaign for the vote, she exclaims that it will 'last all our lifetimes', and goes on: 'As one falls another steps into the breach' (277). The implication that individual lives are expendable and interchangeable reflects badly on Mrs Seal. Anti-war writing emphasised the unique and irreplaceable quality of each human life. Clive Bell's pacifist pamphlet Peace at Once (1915) included a vignette of a local 'shopman' who had died in the war, setting the specifics of his life against abstractions such as 'national honour', 'national existence' and 'civilisation' for which the war was being fought. ${ }^{15}$ An article in the Athenaeum in February 1917 articulated the irreplaceability in terms that more closely contest the trope of the 'breach':

But hardly a soldier has fallen who has not left a niche which can never be filled. the humblest soldier, torn out of the community before his due time, has left a gap, and society is not the same without him, for he was an integral part of it. ${ }^{16}$

\footnotetext{
${ }^{15}$ Clive Bell, Peace at Once (Manchester and London: National Labour Press, 1915), pp. 9-11.

${ }^{16}$ Anon., 'The Purpose of Reconstruction', Athenaeum, February 1917, 63-64.
} 
Whereas the suffrage society and Ralph are characterized by the language of combat, William Rodney is associated, more fleetingly, with the language of military discipline. In the scene where Ralph visits his rooms, in one of two similes his books are 'as orderly as regiments of soldiers'; in the other simile 'the backs of them shone like so many bronze beetle-wings', with the implication that the beetles are dead and in a display case (70). Towards the end of the novel, when he and Katharine finally reveal to Mr Hilbery that their engagement is over, Rodney stands with a 'military rigidity' that is contrasted to $\mathrm{Mr}$ Hilbery's 'pomposity' and Katharine's 'preoccupied naturalness' (496). The references to Katharine's figure as 'commanding' $(95,242)$ might seem to associate her with the military, as might the reference to her 'commanding' tone of voice (211), but we should note Mrs Hilbery's impression of Rodney's manner as 'not commanding': Woolf wishes to distinguish between being 'commanding' and having a military rigidity. More importantly, in the scene where Rodney is characterized as rigid, Katharine's 'naturalness' might suggest that she has grown away from the family traditions that were, earlier on, so restrictive.

Government policies during the First World War brought sharply into focus questions about the relation between state power and individual liberty that had been discussed for many decades. The debate around conscription -- or 'national service' as its advocates called it -- had been rising in prominence since the Boer War. Conscription was often seen as alien to English traditions of individual liberty. ${ }^{17}$ These questions are touched

${ }^{17}$ On the pre-1914 history of the conscription debate, see Denis Hayes, Conscription Conflict (London: Sheppard Press, 1949); Thomas C. Kennedy, The Hound of Conscience: A History of the No-Conscription Fellowship, 1914-1919 (Fayetteville, Ark: University of Arkansas Press, 
upon several times in the novel. In Chapter 24, as the narrator describes Katharine's uneasy relation to traditional authority, we are told that 'She was ready to believe that some people are fortunate enough to reject, accept, resign, or lay down their lives at the bidding of traditional authority' (330), but that she herself found 'traditional answers' unsatisfactory. The possibility of having to lay down one's life at the bidding of a higher authority was unavoidable during the war. Later, in Chapter 27, when Katharine visits the Denham family, an argument springs up about 'whether the Salvation Army has any right to play hymns at street corners on Sunday mornings, thereby making it impossible for James to have his sleep out, and tampering with the rights of individual liberty' (400). Although it is not the state's army that prompts the debate, but the quasi-military Christian evangelical organization established by the self-styled 'General' William Booth (1829-1912) in the 1860s, the mention of an 'Army' nevertheless points towards the war-time era. Katharine joins in the argument, taking the opposite point of view from Ralph, and by the time they have gone to his room, the nub of the question has become abstracted to the extent that Katharine describes it as concerning when it is 'right for the individual to assert his will against the will of the State' (401-02). At one level this scene merely characterises the Denham household as intellectually lively and as offering Katharine a place within its discussions; but at another it seems to hint at ways that the comedic narrative of the liberty of the young couples in relation to the traditional attitudes of the older generation might allusively refer to the contemporary conflict between government and conscripts.

1981), pp. 1-27; R. J. Q. Adams and Philip P. Poirier, The Conscription Controversy in Great Britain, 1900-18 (Basingstoke: Macmillan, 1987), pp. 1-48. 
As well as these verbally specific examples, there are two scenes in the novel that are suggestive of the presence of the war, and particularly of the state's power to mobilise masses of men. The first comes in chapter 28 when, on a windy Sunday night, Ralph goes to Chelsea to see Katharine. On his way, he happens upon an old man on the Embankment who Ralph conjectures has 'drunk himself ... out of work and lodging' (417), who proceeds to tell him a lengthy tale of woe. Ralph's attempts to interrupt him are futile.

And when the elderly man refused to listen and mumbled on, an odd image came to his mind of a lighthouse besieged by the flying bodies of lost birds, who were dashed senseless, by the gale, against the glass. He had a strange sensation that he was both lighthouse and bird; he was steadfast and brilliant; and at the same time he was whirled, with all other things, senseless against the glass. (417-18)

There is a violence about the image that seems out of proportion to the scene, as if the novel wishes to convey something more than Ralph's emotional confusion or his irritation at the old man's senseless rambling. 'Besieged' is specifically military, and in that context the image of the flying bodies of birds dashed senseless against the glass is suggestive. Wussow recognizes the violence, noting a similarity to $\mathrm{D}$. H. Lawrence's phrase about the war as a 'frenzy of blind things dashing themselves and each other to pieces'; noting Ralph's oscillating position in relation to the metaphor, his being 'both lighthouse and bird', she 
argues that the birds 'represent the self's contact with the other'. ${ }^{18}$ I would argue that the image also suggests something less psychological and more topical. It might suggest soldiers propelled against their will to death, at least in an idealised image of battle: accounts of trench warfare tended to emphasise the sheer slowness and difficulty of movement. It might suggest the souls of the dead, often figured as birds: for example the souls that 'Flock silently away' in Sassoon's 'Prelude: The Troops', which Woolf would have read for her review of his volume Counter-Attack in July $1918 .{ }^{19}$

When Ralph reaches the Hilberys' house, with its three long windows, it is transformed into the lighthouse:

The space of the room behind became, in Ralph's vision, the centre of the dark, flying wilderness of the world; the justification for the welter of confusion surrounding it; the steady light which cast its beams, like those of a lighthouse, with searching composure over the trackless waste. In this little sanctuary were gathered together several different people, but their identity was dissolved in a general glory of something that might, perhaps, be called civilization. (418)

\footnotetext{
${ }^{18}$ Wussow, Nightmare, pp. 94-95; the Lawrence quotation comes from 'The Crown' (1915), in Reflections on the Death of a Porcupine and other essays, ed. by Michael Herbert (Cambridge: Cambridge University Press, 1988), p. 259.

${ }^{19}$ Sassoon, 'Prelude: The Troops', in Counter-Attack and Other Poems (London: Heinemann, 1918), pp. 9-10; Woolf, 'Two Soldier-Poets', in Essays, II, 269-72.
} 
Were the lighthouse literal, the 'trackless waste' would be the sea, but it suggests the desolated landscape of the continental battlefields. The question of a 'justification' for a 'welter of confusion' points towards the various attempts to justify the war to combatants and civilians; 'civilization' hints at one well-known justification, the war as a defence of civilisation. As noted earlier, Clive Bell's Peace at Once had mentioned civilization as one of the questionable justifications for the war, and it has been widely noted in relation to Mrs Dalloway that Bloomsbury continued to discuss the idea into the $1920 \mathrm{~s}^{20}$ Ralph's ambiguous position, 'both lighthouse and bird', suggests both that he represents the 'civilisation' that the war was fought to defend, and that he is potentially one of those sacrificed in its defence.

The other comparable scene and image comes when Katharine goes to Lincoln's Inn Fields to look for Ralph Denham at the solicitors' office. The three long windows of the Hilberys' drawing room are echoed by the 'three tall windows' of the offices (465). Failing to find Ralph at the offices, Katharine leaves the square and finds herself in the major thoroughfare of Kingsway.

The great torrent of vans and carts was sweeping down Kingsway; pedestrians were streaming in two currents along the pavements. She stood fascinated the corner.

\footnotetext{
${ }^{20}$ Bell, Peace at Once, p. 10; for discussions of Woolf and the theme of civilization, see Brian W. Shaffer, 'Civilization in Bloomsbury: Woolf's Mrs Dalloway and Bell's "Theory of Civilization,"' Journal of Modern Literature, 19 (1994), 73-87; Christine Froula, Virginia Woolf and the Bloomsbury Avant-Garde: War, Civilization, Modernity (New York: Columbia University Press, 2005), especially pp. 1-32.
} 
The deep roar filled her ears; the changing tumult had the inexpressible fascination of varied life pouring ceaselessly with a purpose which, as she looked, seemed to her, somehow, the normal purpose for which life was framed; its complete indifference to the individuals, whom it swallowed up and rolled onwards, filled her with at least a temporary exaltation. The blend of daylight and of lamplight made her an invisible spectator, just as it gave the people who passed her a semi-transparent quality, and left the faces pale ivory ovals in which the eyes alone were dark. They tended the enormous rush of the current - the great flow, the deep stream, the unquenchable tide. [465-66]

The 'roar' of traffic is a presence throughout the London scenes of the novel. The significant detail here is its 'complete indifference to individuals'. That might seem to make it some kind of life force, but the same indifference was seen in a nation-state that conscripted individuals into its army, and as the passage goes on it seems more like a death force. The novel is full of the language of haunting, and these semi-transparent figures with their dark eyes are a particularly powerful image of ghosts. Some combatant writers figured the war in apocalyptic terms, whether as fire, flood, or storm; so too did contemporary reviewers and journalists. ${ }^{21}$ Woolf's imagery of a roaring, tumultuous current alludes to their figurative language.

\footnotetext{
${ }^{21}$ Jay Winter, Sites of Memory, Sites of Mourning: The Great War in European Cultural History (Cambridge: Cambridge University Press, 1995), pp. 178-203; Samuel Hynes touches briefly on the figure of the deluge in A War Imagined: The First World War and English Culture (London: Bodley Head, 1990), pp. 252-53; on the 'apocalyptic turn', see Mark S.
} 


\section{Night and Day as historical novel}

Night and Day is a novel with a double focus. Ostensibly it is focused on the pre-war years during the suffrage campaign. There are few specific chronological pointers within the text, and many of them are ambiguous, so we cannot date the action precisely, but it seems to take place in the years $1909-1911 .^{22}$ However, as I have suggested, as well as its ostensible focus, it has a subtler second point of focus on the years of its composition, 1915-1919. In presenting the pre-war era, at several points Woolf chooses locations and subjects that were to change significantly in the years that followed, thus creating situational ironies. Ian Blyth has noted how Ralph's simple act of feeding the sparrows (165-66) takes on a different significance when one considers the war-time Defence of the Realm Act. Under the 'Waste of Wheat Order' (1916) and its successor, the 'Wheat, Rye and Rice (Restriction) Order' which came into force on 20 April 1917, the feeding of birds was deemed wasteful: in June 1917 The Times had reported the case of a woman who was fined $£ 2$ for feeding birds. ${ }^{23}$

Morrisson, 'Apocalypse 1917: Esoteric Modernism and the War in Aleister Crowley's Moonchild', Modernist Cultures, 12 (2017), 98-119 (pp. 99-100). For an example of the war as 'deluge,' see Anon., 'The World After the Deluge,' Nation 23 (6 July 1918), p.368.

${ }^{22}$ Michael H. Whitworth, Introduction, Night and Day, ed. by Michael H. Whitworth (Cambridge: Cambridge University Press, 2018), Ixxxix-xci.

${ }^{23}$ Ian Blyth, 'Do Not Feed the Birds: Night and Day and the Defence of the Realm Act', in Contradictory Woolf: Selected Papers from the Twenty-First Annual Conference on Virginia Woolf, ed. by Derek Ryan and Stella Bolaki (Clemson, SC: Clemson University Digital Press, 2012), pp. 278-84. 
A similar example comes during Cassandra Otway's vacation in London: Cassandra not only visits the National Gallery and Hertford House, but attends concerts at the Bechstein Hall. It was possible to go to the Bechstein Hall in 1910, but not in 1917. As enemy aliens, the proprietors Edwin and Carl Bechstein were refused an alcohol licence in November 1915; they sold their businesses in November of the following year, and in January 1917 the hall reopened as the Wigmore Hall. ${ }^{24}$ Virginia Woolf went to the Beethoven concert that opened the hall under its new name. ${ }^{25}$ The relevant chapter of Night and Day was written at some point after April 1918, so Woolf would have been aware that the Bechstein Hall was already a thing of the past. Readers of Woolf are familiar with Miss Kilman in Mrs Dalloway having to conceal her affection for Germany; Night and Day inscribes the effects of the war in the same way, though less insistently.

Mary Datchet's plans for economies in the suffrage society are another glancing reference to war-time conditions. As she walks to work up Southampton Row, Mary thinks 'of notepaper and foolscap', and of 'how an economy in the use of paper might be effected' (76). While an office manager in the period 1909-1911 might plausibly have economized on paper, such economies were not at the forefront of anyone's mind; there were paper shortages in the USA in 1911, but not the UK. ${ }^{26}$ However, not long into the First World War, the shortage of imported timber led to widespread concerns about the paper supply. A Royal Commission on Paper was formed in February 1916; publishers complained of the

\footnotetext{
24 'The Bechstein Hall Licence', Times, 5 November 1915, p.11; 'Bechstein Hall Licence Refused', Times, 27 November 1915, p. 5; 'Bechsteins' Sold', Times, 8 November 1916, p.5. 25 'Beethoven's Violin Sonatas', Times, 17 January 1917, p.11; Woolf, Letters, II, 135.

26 'The Paper Shortage in the States', Times, 11 March 1911, p. 19.
} 
increased price and reduced quality of the paper available to them. ${ }^{27}$ Unlike the absolute impossibility of going to the Bechstein Hall in 1917, this double focus is more a matter of balance: Mary is, without knowing it, engaged in a war-time economy drive. ${ }^{28}$

Images of lights, especially of illuminated windows, which are widely distributed across the novel, also take on different connotations in the context of the war years. There are street lamps being lit $(81,175)$, lamps in shop windows (92), and above all, the lamps in the Hilbery household, which at the opening of chapter 34 are associated very specifically with good wine and civilization. What the lamps might seem to recall is the remark of the Foreign Secretary, Edward Grey, at the start of the war in 1914: 'The lamps are going out all over Europe; we shall not see them lit again in our life-time' ${ }^{29}$ Certainly it is reasonable to relate Grey's phrase to the passage in To the Lighthouse, at the start of 'Time Passes', when 'the lights are all extinguished', but there is no evidence that the phrase was in wide

${ }^{27}$ For contemporary coverage, see, e.g., 'Political Notes', Times, 16 February 1916, p. 9; 'Economy in Paper', Times, 21 February 1916, p. 5; for a more recent account that touches on the problem, Jane Potter, 'For Country, Conscience \& Commerce: Publishers and Publishing 1914-1918', in Publishing in the First World War, ed. by Mary Hammond and Shafquat Towheed (Basingstoke: Palgrave Macmillan, 2007), pp. 11-26.

${ }^{28}$ The term 'reconstruction' is used in association with Mary's plans: it indicates another war-time context too large to be considered in the present article.

${ }^{29}$ Edward Grey (Viscount Grey of Fallodon), Twenty-Five Years 1892-1916, 2 vols (London: Hodder and Stoughton, 1925), II, 20. 
circulation before the publication of Grey's memoirs in $1925 ;^{30}$ and, although the man to whom Grey uttered the phrase, J. A. Spender, editor of the Westminster Gazette, was known to Leonard and Virginia Woolf, there is no evidence that they had heard it from him. ${ }^{31}$ In Night and Day, the connection between the onset of war and the extinction of lamps is less direct: both Grey and Woolf are drawing on the common figure of civilization as a light or lamp. Woolf herself had previously employed this figure: early in The Voyage Out (1915), a lamp above a table is 'the kind of lamp which makes the light of civilisation across dark fields to one walking in the country'. ${ }^{32}$ Around 1914, with a hint of irony, Clive Bell referred to tending 'the lamp' in the 'shrine of civilization' in 'these days of storm and darkness'.$^{33}$

Moreover, in a development that Grey might not have anticipated on 3 August 1914, the first Zeppelin air-raids prompted concerns about lamps deliberately or inadvertently guiding enemy airships, and the Defence of the Realm Act regulations 11 and 12 were brought into force. Regulation 11 gave the Secretary of State the power 'to require extinguishment of lights', while regulation 12 gave similar powers to naval and military

${ }^{30}$ Woolf, To the Lighthouse (London: Hogarth, 1927), p. 195; the echo of Grey is noted by David Bradshaw, ed., To the Lighthouse (Oxford: Oxford University Press, 2006), p. xxv. ${ }^{31}$ Virginia Woolf makes passing reference to Spender being present at a League of Nations meeting on 14 June 1918: Woolf, Diary, I, 157. For Spender's account of Grey's phrase, see J. A. Spender, Life, Journalism, and Politics, 2 vols. (London: Cassell, 1927), II, 14.

32 Virginia Woolf, The Voyage Out (London: Duckworth, 1915), p. 13.

${ }^{33}$ Clive Bell, quoted Elizabeth Outka, Consuming Traditions: Modernity, Modernism, and the Commodified Authentic (Oxford: Oxford University Press, 2009), p. 152. 
authorities. $^{34}$ The difference to the appearance of the city struck Woolf strongly. At the end of the war, as she completed Night and Day, she noted on 12 November 1918 that some shops remained shut, because 'no light yet procurable'. In her diary for 15 November she describes the sensation of the new luminary environment:

Instead of feeling all day \& going home through dark streets that the whole people, willing or not, were concentrated on a single point, one feels now that the whole bunch has burst asunder \& flown off with the utmost vigour in different directions. We are once more a nation of individuals. [...] Coming home from the [1917] Club tonight I thought for a moment that it must still be sunset, owing to the sharp bright lights in Piccadilly Circus. The streets are crowded with people quite at their ease; \& the shops blazoning unshaded lights. ${ }^{35}$

The 1919 reader of the novel might feel that, by the conclusion, the novel's characters have, like the nation, passed through a period of storm and darkness and reached a state of illumination. Forms of the metaphor were widespread: in August 1918 the Archbishop of Canterbury spoke of 'the clouds and darkness of these bewildering days', while in the same month the Prime Minister invoked the metaphor of light at the end of the tunnel. ${ }^{36}$ The victorious blaze of lights at the opening of the final chapter explicitly associates light with the triumph of civilization (531), and at this point the novel might seem to have aligned

\footnotetext{
${ }^{34}$ Alexander Pulling, ed., Defence of the Realm Manual, 2nd enlarged edition, revised to November 30th, 1916 (London: Frederick Attenbury, 1916), p. 12.

${ }^{35}$ Woolf, Diary, I, 217.

36 'Remembrance Day,' Times, 5 August 1918, p.4; 'Fighting for Right,' Times, 10 August
} 1918, p.8. 
itself with the ideal of 'civilization' and with the notion that the war was fought in its defence. However, it is important to remember that the Hilbery family are unaware of the political uses their 'civilization' will be used for in the near future; moreover, as we shall see shortly, their lights are not the only ones visible in the final chapter.

Whether feeding sparrows, visiting the Bechstein Hall, or enjoying the benefits of artificial light, the characters are framed by a situational irony. The reader knows what is to come, but they do not. It is possible, of course, that some of these ironies crept up on Woolf accidentally: it is possible that she had planned to depict Ralph's kindness to birds before the DORA regulations came into force; it is possible that she had planned to have the characters visit the Bechstein Hall because she herself had done so in the pre-war years. ${ }^{37}$ Nevertheless, as she entered the final phase of revision of the novel in March 1919, the ironies that had accrued around these instances would have been clear to her. ${ }^{38}$ Even if the ironies were not originally intended, they were authorially endorsed.

The novel also includes a scene that more directly comments on the situational ironies of history. When Katharine receives Ralph's telephone call, the Hilberys' telephone is located in an alcove which is full of 'superfluous possessions', 'the wreckage of three generations' (326-27). Having felt 'impinged upon a bayonet' by Ralph's call, Katharine drops the telephone receiver and '[looks] fixedly at the print of the great-uncle who had not ceased to gaze, with an air of amiable authority, into a world which, as yet, beheld no

\footnotetext{
37 She had attended a concert there in May 1905: Woolf, A Passionate Apprentice: Early Journals, ed. by Mitchell A. Leaska (London: Chatto \& Windus, 1990), pp. 270-71. 38 In March 1919 Woolf was making corrections and typing up her manuscript: Diary I, 250; Letters II, 339.
} 
symptoms of the Indian Mutiny' (327). The conjunction of the character's thoughts and feelings with an apparently unrelated and incongruous external object or event becomes, in Woolf's later novels, a carefully crafted device for insinuating an additional aspect to the character's inner life; the conjunction places the reader in the position of solving a riddle, deciding whether the inner and outer are indeed incongruous, or whether they are connected by a hidden logic. In Night and Day's own internal terms, what this particular conjunction might betoken is Katharine's intuition that something momentous is about to occur. But this conjunction brings an additional complexity, because, reminded by the reference to a bayonet, the reader is aware that the characters themselves are living in a state of blissful ignorance about what is to come in European history; the supposed calm and complacency of the British Empire before the Indian Mutiny of 1857 anticipates what seemed in retrospect as the pre-war calm of England. In its attention to situational ironies, the project of Night and Day is not so very different from that of its experimental modernist successor, Jacob's Room. Though in Jacob's Room Woolf devises subtle means for signalling the coming disaster, she also deploys some astonishingly straightforward hints: above all, Jacob's surname, Flanders; but also the moment where she depicts young men at Cambridge reading, smoking, sprawling over tables, and then interrupts her own speculation about what they would go on to do, saying 'there is no need to think of them grown old'. ${ }^{39}$ The image of Katharine's great uncle's impercipience is far subtler, but likewise hints at the coming disaster.

An ambiguous phrase in the closing pages of the novel might encourage us to take the question further. Walking in central London with Katharine, Ralph sees Mary's light on,

${ }^{39}$ Woolf, Jacob's Room (London: Hogarth, 1922), p. 67. 
and ascends her stairs with the intention of calling on her, but, on reaching her door, cannot bring himself to knock. The description of the window from Katharine's perspective, while she waits in the street for Ralph, picks up on the term 'triumphed' that appeared at the start of the final chapter, but twists it:

Katharine stood where he left her, looking at the window and expecting soon to see a shadow move across it; but she saw nothing; the blinds conveyed nothing; the light was not moved. It signalled to her across the dark street; it was a sign of triumph shining there for ever, not to be extinguished this side of the grave. (535-36)

The word 'signalled' is incidentally interesting, given war-time fears about lights in windows being used as signals to the enemy, but the reminder of death in Ralph and Katharine's newfound arcadia is the phrase 'this side of the grave'. Ralph returns and explains that he couldn't bring himself to knock on Mary's door.

They stood for some moments, looking at the illuminated blinds, an expression to them both of something impersonal and serene in the spirit of the woman within, working out her plans far into the night-her plans for the good of a world that none of them were ever to know. (536).

That final phrase admits of a slight grammatical ambiguity about whether it is the plans or the future world that none of them were ever to know, but the latter is the one best served by the word order, and assuming that it is intended, we might stop to ask why they will never know that world. One possibility is that the creation of a truly democratic and fair society is a long-term project that will be the work of many lifetimes; another more 
pessimistic possibility is that the project is hopelessly idealistic and unrealizable in any length of time. But we might think about Ralph being twenty-nine years old near the beginning of the story (130). If we grant that the novel is set around 1909, he was born around 1880. In January 1916 conscription had been introduced for unmarried men between the ages of 18 and 40, and by May 1916 it had been extended to married men between 18 and 41: Ralph, whether married to Katharine or not, could have been conscripted. ${ }^{40}$ There were exemptions for 'reserved' or 'certified' occupations but no exemption that would fit Ralph's case, whether as a solicitors' clerk or an amateur historian. ${ }^{41}$ The passage states that 'none of them' would ever know Mary's future world, meaning Mary and Katharine as well as Ralph, and as conscription was aimed solely at men, a death in combat seems unlikely for them, though it is possible to imagine other fates during the war: they might become casualties on the home-front or as members of a voluntary aid detachment; they might die for reasons unconnected to the war. Even if we resolve the ambiguity of this particular phrase in other ways, the figure of Katharine's great uncle still presides over the text, reminding us that there is a future in store for the characters which they cannot have imagined, and allowing us to re-read Night and Day as if it were 'The Window' section of To the Lighthouse.

40 'The New Bill', Times, 5 May 1916, p. 9; John Williams, The Home Fronts: Britain, France and Germany 1914-1918 (London: Constable, 1972), pp. 112-13.

${ }^{41}$ Military Service Act, 1916: Certified Occupations (London: HMSO, 1916). 


\section{Isolation and obliviousness}

The last two paragraphs of Mansfield's review of Night and Day contain a significant sleight of hand in which she conflates the outmoded and inaccessible world that the principal characters inhabit with the outmodedness of the novel itself. She turns from describing the 'dream world' of Ralph and Katharine to the 'real world' of 'Mr and Mrs Hilbery, William Rodney, Cassandra Otway'.

It is so far away, so shut and sealed from us to-day. What could be more remote than the house at Cheyne Walk, standing up in the night, with its three long windows gilded with light, its drawn velvet curtains, and the knowledge that a young creature is playing Mozart, Mrs Hilbery is wishing there were more young men like Hamlet, and Katharine and Rodney are faced by the incredible sight of Denham, outside in the dark, walking up and down ... [ellipses in the original text]

We had thought that this world was vanished for ever, that it was impossible to find on the great ocean of literature a ship that was unaware of what has been happening. Yet here is 'Night and Day', fresh, new and exquisite, a novel in the tradition of the English novel. In the midst of our admiration it makes us feel old and chill: we had never thought to look upon its like again! ${ }^{42}$

In other words, she identifies the aloof classicism of the novel, its isolation from contemporary developments, with the comfortable and secluded world of the Hilbery family. Later critics have taken their cue from Mansfield, favouring tropes of isolation and

${ }^{42}$ Mansfield, 'A Ship Comes into the Harbour', p. 1227. 
insulation: for Briggs the novel is 'a comedy of manners insulated against unwelcome eruptions or interruptions'. ${ }^{43}$ But isolation and insulation are far more than formal qualities of the work: they are also attitudes that, however tentatively, Night and Day depicts and critically examines.

The theme of isolation, already noted in relation to the 'thousand softly padded doors' that seem to separate the Hilbery drawing-room from the noise of the street, runs throughout the novel; connected to it is a theme of near obliviousness. The obliviousness is not complete, because characters are consistently troubled by the partial knowledge of something beyond their own self-contained worlds. This troubled feeling is one motivating force behind the novel's extensive use of the language of ghosts and haunting: there is something consistently uncanny at work. During Ralph's first visit to the Hilbery household, he views the chapel- or grotto-like room of relics relating to their celebrated ancestor, the poet Alardyce, but even in this sanctus sanctorum the sound of the traffic outside can be heard faintly 'booming' (7). The narrator describes the sound as being suggestive of 'the soft surge of waters', but for an immediately post-war reader, particularly in the south of England, 'booming' would have suggested the sound of guns and bombs, whether heard at the front, heard across the English Channel, or heard in London during air-raids. In Woolf's essay on cross-Channel noises, 'Heard on the Downs: The Genesis of Myth' (August 1916), published during the early phase of her composition of Night and Day, the paradoxical and uncanny quality of the sound is crucial. In a phrase that Woolf would re-work in the penultimate chapter of Jacob's Room, the guns in France sound like 'the beating of gigantic

\footnotetext{
43 Julia Briggs, Virginia Woolf: An Inner Life (London: Allen Lane, 2005), 29.
} 
carpets by gigantic women' ${ }^{44}$ Walks on the South Downs 'are accompanied by this sinister sound of far-off beating': 'Often walking alone, with neither man nor animal in sight, you turn sharply to see who it is that gallops behind you. But there is no one. The phantom horseman dashes by with a thunder of hoofs, and suddenly his ride is over and the sound lapses, and you only hear the grasshoppers and the larks in the sky. ${ }^{\prime 45}$ The distant sounds of battle are mentioned several times in Woolf's Asheham diary in August and September of 1917; in early September 1917, she notes that thunder claps are indistinguishable from guns. ${ }^{46}$ Southern England was simultaneously isolated from the war and yet troublingly reminded of it, and the language of Gothic, even if it involved fanciful phantom horsemen, was one method of attempting to articulate the associated uncomfortable feeling.

One diary entry, written by Woolf in Richmond in December 1917 following an airraid, gives some indication of the distinctive soundscapes of suburban London in wartime, and the heightened sensitivity to sound of the civilian population:

They [the guns] fired very quickly, apparently towards Barnes. Slowly the sounds got more distant, \& finally ceased; we unwrapped ourselves \& went to bed.

But ten minutes later, the gunfire resumes, 'apparently at Kew':

\footnotetext{
${ }^{44}$ Woolf, Jacob's Room (1922), p. 288; 'Heard on the Downs', Essays, II, 40.

${ }^{45}$ Woolf, 'Heard on the Downs', Essays, II, 40.

${ }^{46}$ Woolf, Diary, I, 40, 48, 49.
} 
Guns at one point so loud that the whistle of the shell going up followed the explosion. One window did, I think, rattle. Then silence. Cocoa was brewed for us, \& off we went again. Having trained one's ears to listen one can't get them not to for a time; \& as it was after 6 , carts were rolling out of stables, motor cars throbbing, \& then prolonged ghostly whistlings which meant, I suppose, Belgian work people recalled to the munitions factory. ${ }^{47}$

Although the Gothic element is not nearly so pronounced as in 'Heard on the Downs', the ghostliness of the factory sirens suggests it. In this passage, as elsewhere in her wartime diaries, Woolf was a keen observer of her responses to the subtle indicators of possible imminent catastrophe: in the present passage the indicators are aural, but elsewhere they are visual, as when 'the dipping down of the electric lights' becomes 'a sign of warning. ${ }^{48}$ Throughout Night and Day, characters repeatedly hear sounds from beyond their enclosed domestic worlds. In Chapter 8, Katharine opens a window, and admits 'the distant humming sound of far-off crowded thoroughfares' (106) - but even through an open window the sound is distant. In the following chapter, Katharine strains her ears and can 'just hear, far off, the hoot of a motor-car and the rush of wheels coming nearer and dying away again, and the voices of men crying old iron and vegetables in one of the poorer streets at the back of the house' (114). Katharine's heightened auditory sensitivity is a trace of the novel's wartime composition and of the informal 'training' that Woolf alludes to in the quoted diary entry.

\footnotetext{
47 Woolf, Diary, I, 85.

48 Woolf, Diary, I, 70.
} 
In this connection, Katharine's sense of powerlessness, as she and her mother fail to make progress with the biography of Alardyce, is particularly resonant. Mrs Hilbery laments that she might die before it is completed, and her depression communicates itself to her daughter: 'How impotent they were, fiddling all day long with papers! And the clock was striking eleven and nothing done!' (116). Eleven might signify the time for a mid-morning break, but 11 p.m. was the time at which war was originally declared, and 11 a.m. was the time at which the armistice began on the eleventh day of the eleventh month in 1918. Katharine and Mrs Hilbery are the counterparts of the 'sixteen gentlemen' at the close of Jacob's Room, who through the medium of writing are able to determine the course of history; but the gentlemen have power, while Katharine and her mother do not. ${ }^{49} \mathrm{At}$ moments like this, the novel is pessimistic about the power of civilization to resist the ticking clock and the global calamities it symbolizes. The confidence of the narrator's statement at the end of the novel that 'civilization had triumphed' is severely qualified by what we have learned of its custodians. Charming though Mrs Hilbery is, at the end of the novel she is no nearer to completing Alardyce's biography than she was at the start. For Mr Hilbery, civilization is so fragile that it can be 'very profoundly and unpleasantly overthrown' by the romantic misdemeanours of the younger generation. While he tries to restore civilization by reading aloud the works of Sir Walter Scott, he asks himself 'was literature itself a specific against such disagreables?'; the 'note of hollowness' in his voice implies an answer in the negative (505). Civilization, at least in its old form, is impotent. The disruption caused by the younger generation within the house is nothing compared to the noises of

\footnotetext{
${ }^{49}$ Woolf, Jacob's Room, p. 282.
} 
the modern world outside, and they in turn are nothing to the noises coming from France and Belgium.

As well as feeling isolated from a world that is distant, noisy, and modern, characters feel isolated from one another, and the novel's ongoing attention to the limitations of language is one aspect of the theme. Katharine considers the incompatible interpretations that she, William Rodney, Ralph Denham, and Mary Datchet place on the word 'love' and the 'confusion of lives which, instead of running parallel, had suddenly intersected with each other' (331). The implication is that their parallel lives should never meet, and that, although by some quirk of fate and geometry their lives have coincided, their languages have not. The question of language culminates in Ralph's doodles of 'blots fringed with flames' and Katharine's acknowledgement of them: a language beyond language $(516,522)$. The isolation is also that of one generation from another, and of the living generations to their dead ancestors. Katharine, brought up 'in a tradition' (329), has an ambiguous relationship to the older generation: she can 'reduce any moral difficulty to its traditional shape and solve it by the traditional answers' (329), but finds such answers 'of no use to her individually' (330). Night and Day is, in part, the story of Katharine's attempt to find useable answers. Early in the novel, sitting in the Hilbery writing room contemplating the 'vanished figures' of Alardyce's generation, the conventional temporality of haunting is reversed, and Katharine 'seemed to herself to be moving among them, an invisible ghost among the living, better acquainted with them than with her own friends'. She feels she could have corrected the vanished generation, 'could have told them what to do, and what not to do', but that they 'would pay no heed to her, and were bound to come to grief in their own antiquated way' (115). These reflections follow Katharine's hearing the far-off motor car (114) and lead into her reflections on her impotence (116); Katharine's frustration registers the frustration 
of a younger generation with an older generation of political and military leaders. While solipsism and the isolation of one person from another are themes that endure in Woolf's later fictions, they have more specific meanings within their historical context. Park notes the 'gulf' in the novel between 'the world of high culture and the world of suffrage', ${ }^{50}$ but I would suggest that, if we taken the novel's war-time composition context into account, its gulfs also signify other schisms: between London and the continent; between the younger generation and the old; and between the world of high culture and the war.

\section{Conclusion}

Did Katherine Mansfield misread Night and Day? Mansfield remarked upon the absence of any scars', but the evidence gathered here suggests that the scars are visible. If the war is a presence in the novel, how did Mansfield fail to notice it? It is a failure all the more surprising given her own employment of the language of war in her war-time correspondence. ${ }^{51}$ The simplest answer is that the traces that Woolf inscribed into the novel were noticeable, but not conspicuous enough to satisfy Mansfield's desire for a novel that registered 'a change of heart'. Moreover, because Night and Day is conventional in its plot (a marriage comedy) and in its narratorial mode, the reader is not encouraged to interpret in ways that foreground the symbolic, the analogical, and the allusive elements in the text.

${ }^{50}$ Park, 'Suffrage and Virginia Woolf', p. 129.

${ }^{51}$ Alice Kelly, 'Mansfield Mobilised: Katherine Mansfield, the Great War and Military

Discourse,' Modernist Cultures 12 (2017), pp. 78-97. 
In 1926 E. M. Forster reinforced Mansfield's appraisal, describing Night and Day as ‘a deliberate exercise in classicism. ${ }^{52}$ The few remarks that Woolf made about the novel during her lifetime acquiesced in the estimates of others. In 1930 in a letter to Ethel Smyth, Woolf described the process of composition as if it had been an academic art-school task, 'copy[ing] from plaster casts'. ${ }^{53}$ Coupled with E. M. Forster's account of the novel, Woolf's remark has often been taken to imply that what she learned to write was a conventional realist work in the manner of Jane Austen. However, there are distinct signs that in writing The Voyage Out she had already learned how to make coded references to controversial and uncomfortable subject-matter. The evidence considered above suggests that in writing Night and Day she was not only copying plaster-casts, but making her own subtle variations on them.

Although Mansfield's judgement about Night and Day has contributed to its critical neglect, by mentioning the war in her letter to Murry, she also posed a problem for future critics. Mansfield apparently came to the novel hoping for a development of the aesthetic experiments she had seen in Woolf's 'The Mark on the Wall' and in the manuscript of 'Kew Gardens. ${ }^{54}$ Those hopes were disappointed. If her expectation that the novel would

${ }^{52}$ E. M. Forster, 'Virginia Woolf' (1926), reprinted in Virginia Woolf: The Critical Heritage, ed. by Robin Majumdar and Allen McLaurin (London: Routledge \& Kegan Paul, 1975), p. 173. 53 Woolf, Letters, IV, 231.

${ }^{54}$ The former was published (in Two Stories) in July 1917. Mansfield's praise in a letter of Woolf's 'Flower Bed' is usually taken to refer to a draft of 'Kew Gardens': Mansfield, letter to Virginia Woolf, c.23 August 1917, Collected Letters of Katherine Mansfield, ed. Vincent O'Sullivan and Margaret Scott, 5 vols. (Oxford: Clarendon, 1984-2008), I, 327. 
acknowledge the war were encouraged by the prominence of pacifism in Woolf's social circles, it may have been stimulated further by precisely the subtle allusions that the present article has traced. The novel's uses of martial metaphors, its awareness of historical change, and its references to distant disturbing noises did not exactly meet Mansfield's expectations. They were perhaps sufficient to remind her of 'what [had] been happening' historically, but insufficient to address the war satisfactorily. 